\title{
UBQLN4 wt Allele
}

National Cancer Institute

\section{Source}

National Cancer Institute. UBQLN4 wt Allele. NCI Thesaurus. Code C118580.

Human UBQLN4 wild-type allele is located in the vicinity of $1 \mathrm{q} 21$ and is approximately 18 $\mathrm{kb}$ in length. This allele, which encodes ubiquilin-4 protein, may play a role in the regulation of the proteasome. 